\title{
PENGARUH MODEL PEMBELAJARAN TEAM ASSISTED INDIVIDUALIZATIONBERBASIS PENILAIAN KINERJA TERHADAP KOMPETENSI PENGETAHUAN MATEMATIKA SISWA KELAS V SD GUGUS II KUTA UTARA TAHUN PELAJARAN 2017/2018
}

\author{
Ni Luh Nita Suci Widiasih ${ }^{1}$, I Wayan Wiarta ${ }^{2}$, I Ketut Ardana ${ }^{3}$ \\ 1,2,3 Jurusan Pendidikan Guru Sekolah Dasar, Universitas Pendidikan Ganesha, Singaraja \\ email: nitasuci19@yahoo.co.id', iwayan.wiarta@undiksha.ac.id², \\ ketut_ardana55@yahoo.com ${ }^{3}$
}

\begin{abstract}
Abstrak
Penelitian ini bertujuan untuk mengetahui pengaruh model pembelajaran team assisted individualization berbasis penilaian kinerja terhadap kompetensi pengetahuan matematika siswa kelas V sekolah dasar gugus II Kuta Utara tahun pelajaran 2017/2018. Jenis penelitian ini adalah penelitian eksperimen semu dengan menggunakan desain penelitian nonequilvalent control group design. Populasi penelitian ini adalah seluruh siswa kelas V SD Gugus II Kuta Utara tahun pelajaran 2017/2018 sebanyak 334 siswa. Sampel penelitian ditentukan dengan teknik random sampling. Sampel dalam penelitian ini adalah kelas V SD No. 3 Canggu sebagai kelompok eksperimen dan kelas VB SD No. 1 Tibubeneng sebagai kelompok kontrol yang berjumlah 66 siswa. Data kompetensi pengetahuan matematika peroleh dengan instrumen berupa tes pilihan ganda biasa. Selanjutnya data dianalisis dengan uji-t. Hasil analisis menunjukkkan bahwa terdapat perbedaan yang signifikan kompetensi pengetahuan matematika antara kelompok siswa yang dibelajarkan menggunakan model pembelajaraan team assisted individualization berbasis penilaian kinerja dan yang dibelajarkan menggunakan pembelajaran konvensional pada siswa kelas V SD Gugus II Kuta Utara tahun pelajaran 2017/2018. Hal tersebut dibuktikan dengan hasil $t_{\text {hitung }}=4,072>t_{\text {tabel }}=2,000$ pada taraf signifikansi $5 \%$ dengan $\mathrm{dk}=\mathrm{n} 1+\mathrm{n} 2-2=(33+33-2)=64$. Demikian pula nilai rata-rata kompetensi pengetahuan matematika siswa kelompok eksperimen $\bar{X}=75,71>\bar{X}=61,00$ rata-rata kompetensi pengetahuan matematika siswa kelompok kontrol. Dengan demikian dapat disimpulkan bahwa terdapat pengaruh model pembelajaran Team Assisted Individualization berbasis penilaian kinerja terhadap kompetensi pengetahuan matematika siswa kelas V sekolah dasar gugus II Kuta Utara Tahun Pelajaran 2017/2018.
\end{abstract}

Kata kunci: eam assisted individualization, penilaian kinerja, kompetensi pengetahuan matematika

\section{Abstract}

This research aimed to determine the influence of learning model team assisted individualization, based dreaded performance against the competency knowledge mathematic students of class V elementary school Gugus II Kuta Utara in the academic year 2017/2018. This research is an experimental research with the research design is quasi-exsperimental design ( nonequivalent control group design). The population in this research is all class $V$ elementary school Gugus II Kuta Utara in the academic years 2017/2018 as many as 334 students. Research sample is determined by random sampling technique. The sample in this research is class $V$ elementary school No. 3 Canggu as experimental group and class VB elementary school No. 1 Tibubeneng as control group. That amounts 66 students. The mathematic knowledge competence control data is collected with instruments in the from of multiple choice test. Than the data is analyzed by $t$-test. The result of the analysis shows that there is a significant difference of mathematic knowledge competence among group of students who are tought using learning model team assisted individualization based dreaded performance and teach using konvensional learning on the students class $V$ elementary school Gugus II Kuta Utara academic year 2017/2018. This is evidenced by the $T_{\text {count }}$ of $=4,072>T_{\text {table }}=2,000$ at the significant level of $5 \%$ with $D K=n 1+n 2-2 \quad(33+33-2=64)$. Similary the average score of knowledge competence of mathematic student experimental group $\bar{X}=75,71>\bar{X}=61,00$ average of 
mathematic knowledge competence of control group students. This it can concoulde that the application of model team assisted individualization based dreaded performance against of competency mathematic knowledge students class V elementary school Gugus II Kuta Utara academic yesrs 2017/2018.

Keywords : team assisted individualization, dreaded performance, competence knowledge mathematic

\section{Pendahuluan}

Pendidikan memiliki peran penting dalam pembangunan suatu negara. Pembangunan suatu negara akan berjalan dengan baik apabila memiliki sumber daya manusia yang berkualitas. Peningkatan kualitas sumber daya manusia tidak lepas dari peran lembaga pendidikan yang senantiasa berupaya untuk mengembangkan potensi siswa. Upaya untuk mengembangkan potensi peserta didik salah satunya adalah perubahan kurikulum yang disempurnakan untuk mencapai tujuan pendidikan. Kurikulum 2013 mengusung adanya keseimbangan antara kempetensi sikap (attitude), pengetahuan (knowledge), dan keterampilan (skill).

Dalam kurikulum 2013 proses pembelajaran menggunakan tema dimana semua mata pelajaran dikaitkan menjadi satu dalam sebuah tema. Namun di tahun 2017 khusus untuk mata pelajaran penjaskes dan matematika sudah tidak menjadi satu dalam pembelajaran tema. Pembelajaran kurikulum 2013 menggunakan pembelajaran konvensional untuk memberikan pemahaman kepada siswa dalam mengenal, memahami berbagai materi dan mengajarkan bahwa informasi bias berasal dari mana saja tidak hanya dari guru. "Pengalaman belajar yang mereka peroleh tidak bersifat indoktrinisasi, hafalan, dan sejenisnya. Pengalaman belajar, baik itu yang berupa pengetahuan, keterampilan, dan sikap mereka diperoleh berdasarkan kesadaran dan kepentingan mereka sendiri" (kosasih, 2014:72). Kurikulum 2013 memberikan kesempatan kepada siswa untuk mengembangkan perbedaan dalam kemampuan dan minatnya.

Pembelajaran yang telah dilakukan guru di SD Gugus II Kuta Utara sudah berjalan dengan baik, namun masih perlu adanya inovasi dalam proses pembelajaran guna mencapai hasil yang maksimal. Hal tersebut dapat dilakukan pada proses pembelajaran terutama saat pembelajaran secara berkelompok, teramati pada saat diskusi kelompok, hanya siswa yang pintar saja yang terlibat aktif dan bekerja dengan sungguh-sungguh sedangkan siswa yang lainnya hanya diam saja. Teramati juga siswa kurang percaya diri pada saat mengomunikasikan hasil kerja kelompok di depan kelas. Proses pembelajaran seperti ini dapat mengakibatkan pem-belajaran menjadi kurang bermakna sehingga siswa merasa jenuh dan kurang paham dengan muatan materi yang dipelajari, khususnya muatan materi matematika.

Penilaian yang dapat digunakan pada saat pembelajaran tidak hanya penilaian kompetensi pengetahuan namun penilaian dapat dilakukan pada kinerja siswa. Kinerja siswa dapat dilihat pada saat siswa berdiskusi dengan kelompok dan mengerjakan tugas kelompoknya. Penerapan mode pembelajaran yang sesuai dapat membuat pembelajaran terasa menyenangkan serta membuat siswa lebih aktif dalam pembelajaran. Salah satu model pembelajaran yang dapat digunakan adalah model pembelajaran team assisted individualization berbasis penilaian kinerja. Salvin (Faturrohman, 2015:73) menyatakan, team assisted individualization juga melihat siswa untuk bersosialisasi dengan baik, dan ditemukan adanya pengaruh positif hubungan dan sikap terhadap siswa yang terlambat akademis. Kelebihan dalam menggunakan model pembelajaran team assisted individualization.

Menurut Shoimin (2014) model pembelajaran ini memiliki beberapa kelebihan diantaranya adalah, siswa yang lemah dapat terbantu dalam menyelesaikan masalahnya, siswa yang pandai dapat mengembangkan kemampuan dan keterampilannya, adanya 
tanggung jawab dalam kelompok dalam menyelesaikan permasalahannya, siswa diajarkan bagaimana bekerja sama dalam suatu kelompok.

Menurut Sohimin (2014:200) model pembelajaran team assisted individualization ini memiliki 8 tahap yaitu: (1) placement test, guru memberikan tes awal kepada siswa (2) teams, guru membentuk kelompok 4-5 siswa (3) teaching group,guru menjelaskan pemberian tugas kelompok (4) student creative, siswa mengerjakan tugas individunya (5) team study, siswa mengerjakan tugas bersama kelompoknya (6) fact test, guru memberikan tes-tes kecil seperti kuis (7) team score and team recognition, guru memberikan skor pada setiap kelompok (8) whole-class units, guru menyajikan kembali materi dengan strategi pemecahan masalah.

Penerapan model team assisted individualization ini disertai dengan penilaian kinerja. Supardi (2012:31) menyatakan, Penilaian Kinerja merupakan "penilaian yang dilakukan dengan mengamati kegiatan peserta didik dalam melakukan sesuatu" Penilaian ni dapat membantu guru untuk mengetahui peningkatan kinerja siswa dalam proses pembelajaran dan membuat siswa lebih aktif dan bertanggung jawab pada kelompoknya. Dengan demikian, penelitian ini diusulkan dengan judul Pengaruh Model Pembelajaran Team Assisted Individualization Berbasis Penilaian Kinerja Terhadap Kompetensi Pengetahuan Matematika Siswa Kelas V SD Gugus II Kuta Utara Tahun Pelajaran 2017/2018.

\section{Metode}

Pelaksanaan penelitian dila-kukan di SD Gugus II Kuta Utara. Waktu penelitian terkait dengan penelitian ini dilaksanakan selama 2 bulan mulai Maret sampai dengan April 2018, perlakuan sebanyak 6 kali di kelompok eksperimen. Jumlah perlakuan yang diberikan telah disesuaikan dengan jam pelajaran terkait materi dalam penelitian ini yang telah diatur dalam kurikulum dan silabus.

Jenis penelitian yang diguna-kan adalah eksperimen semu (quasi experiment). Penelitian eksperimen semu ini membandingkan dua kompentensi kelompok sampel yang dibelajarkan dengan model pembelajaran team assisted individualization berbasis penilaian kinerja dan yang dibelajarkan dengan pembelajaran konvensional, yang mana kedua pembelajaran tersebut mempunyai pengaruh terhadap satu variabel terikat (Kompetensi). Hal ini dikarenakan kemampuan peneliti da-lam mengamati perilaku siswa sangat terbatas terutama ketika siswa ber-ada di luar sekolah (rumah), peneliti juga tidak memiliki kemampuan untuk mengetahui persepsi siswa terhadap perlakuan secara pasti. Desain eksperimen yang digunakan adalah "nonequivalent control group design". Pada desain ini kedua kelompok yang akan diteliti diberikan pre test dan post test. Pre test tidak dianalisis tetapi hanya digunakan untuk penyetaraan kelompok. Teknik yang digunakan dalam peyetaraan kelompok adalah dengan menggunakan teknik matching. Setelah itu peneliti memberikan perlakuan, yaitu dengan menerapkan model pembelajaran team assisted individualization kepada kelompok eksperimen, dan pembelajaran konvensional pada kelas kontrol.

Sugiyono (2014:117) menyatakan, "Populasi adalah wilayah generalisasi yang terdiri atas : objek/subjek yang mempunyai kualitas dan karkteristik tertentu yang ditetapkan oleh peneliti untuk dipelajari dan kemudian ditarik kesimpulannya". Populasi penelitian ini adalah seluruh siswa kelas V SD Gugus II Kuta Utara tahun pelajaran 2017/2018 yang berjumlah 334 siswa. Sampel adalah bagian dari jumlah dan karakteristik yang dimiliki oleh populasi (Sugiyono, 2014:118). Teknik pengambilan sampel pada penelitian ini dilakukan dengan cara teknik random sampling, karena dalam penelitian ini dipilih 2 kelompok yang dijadikan subjek penelitian. Terdapat sebanyak 10 kelas V yang terdiri dari 7 SD di Gugus II Kuta Utara. Setelah mendapatkan 2 kelompok yang diperoleh dari hasil random sampel kelompok, maka selanjutnya 2 kelompok yang terpilih diberikan pre test. Pre test yang diberikan untuk menyetarakan kelompok. Penyetaraan kelompok dilakukan dengan teknik matching. Darmadi $(2014,234)$ menyatakan, matching adalah "suatu teknik untuk menyeragamkan kelompok pada suatu varia-bel atau lebih yang oleh peneliti telah diitentifikasikan mempunyai hubung-an yang erat dengan penampilan (performance) variabel tidak bebas." 
Setelah didapatkan pasangan dengan nilai yang sama maka 2 kelompok tersebut dikatakan setara. Berdasarkan hasil penyetaraan yang telah dilakukan terdapat 33 pasang siswa yang memiliki nilai yang sama, yaitu 33 siswa dari Kelas V SD No. 3 Canggu dan 33 siswa dari kelas VB SD No. 1 Tibubeneng. Selanjutnya dilaku-kan pengundian untuk menentukan kelas kontrol dan kelas eksperimen. Sehingga populasi sampel yang digunakan dalam penelitian ini berjumlah 66 siswa, yaitu 33 siswa dari SD No. 3 Canggu sebagai kelompok eksperimen dengan diberiperlakuan berupa model pembelajaran team assisted individualization berbasis penilaian kinerja dan 33 siswa dari SD No. 1 Tibubeneng sebagai kelompok kontrol dengan diberi perlakuan berupa pembelajaran konvensional.

Data yang dikumpulkan dalam penelitian ini adalah data kompetensi pengetahuan matematika siswa kelas V SD Gugus II Kuta Utara Tahun Pelajaran 2017/2018. Teknik pengumpulan data ada dua yaitu dengan teknik tes dan teknik non tes, namun dalam penelitian ini, metode pengumpulan data yang digunakan adalah metode tes. Kegiatan pengumpulan data dilaksanakan pada siswa kelas V SD di SD Gugus II Kuta Utara Tahun Pelajaran 2017/2018 yang menjadi anggota sampel. Data tentang kompetensi pengetahuan matematika dikumpulkan dengan tes kompetensi pengetahuan matematika. Menurut Supardi (2015:09), Tes adalah sejumlah pertanyaan yang diajukan oleh evaluator secara lisan atau tertulis yang harus dijawab oleh peserta tes (testee) dalam bentk lisan atau tulisan" (Supardi, 2015:09). Tes yang akan digunakan untuk mengukur kompetensi pengetahuan matematika berupa tes objektif dalam bentuk pilihan ganda biasa. Rancangan penelitian yang digunakan dalam penelitian ini adalah kuantitaif dengan menggunakan uji-t sebagai alat untuk menganalisis data. Deskripsi data hasil kompetesnsi pengetahuan matematika siswa yang dipaparkan meliputi nilai rerata, varians, dan standar deviasi.

\section{Hasil dan Pembahasan}

Kelas V SD No. 3 Canggu ditetapkan sebagai kelompok eksperimen yang diberi perlakuan berupa pengaruh model pembelajaran model pembelajaran team assisted individualization berbasis penilaian kinerja sebanyak 6 kali pertemuan, selanjutnya diberikan post test untuk memeroleh hasil kompetensi pengetahuan matematika.

Nilai mean atau rerata kom-petensi pengetahuan matematika siswa yang mengikuti pembelajaran menggunakan model pembelajaran team assisted individualization berbasis penilaian kinerja, yaitu $=75,71$ dengan varians 182,42 dan standar deviasi $(s=13,51)$, sedangkan nilai mean atau rerata kompetensi pengetahuan matematika siswa yang mengikuti pembelajaran konvensional, yaitu $=61,00$ dengan varians 248,19 dan standar deviasi $(s=15,75)$.

Perhitungan analisis data hasil penelitian yang diperoleh menunjukkan bahwa kompetensi pengetahuan matematika kelompok eksperimen yakni siswa yang mengikuti pembelajaran yang menggunakan model pembelajaran team assisted individualization berbasis penilaian kinerja memiliki nilai mean lebih tinggi daripada kelompok kontrol yakni siswa yang mengikuti pembelajaran konvensional yaitu $=75,71>=61,00$.

Uji prasyarat dilakukan ter-lebih dahulu sebelum uji hipotesis menggunakan uji-t. Uji prasyarat ter-sebut meliputi uji normalitas dan uji homogenitas varians diuraikan ber-ikut ini.

Uji normalitas dilakukan untuk mengetahui sebaran frekuensi skor, untuk menguji data kompetensi pengetahuan matematika kelompok eksperimen dan kontrol adalah rumus Chi Kuadrat. Kriteria pengujian pada uji normalitas adalah jika x2hitung < x2tabel maka sebaran data kedua kelompok berdistribusi normal. Berdasarkan hasil uji normalitas kelompok eksperimen, diperoleh Chi Kuadrat hitung (x2hitung= 7,323) kemudian nilai tersebut dibandingkan dengan Chi Kuadrat tabel dengan taraf signifikan 5\% dk 5 (x2tabel= 11,070). Hal ini menunjukkan bahwa x2hitung < x2tabel berarti data hasil kompetensi pengetahuan matematika kelompok eksperimen berdistribusi normal. Beedasarkan hasil uji normalitas kelompok kontrol, diperoleh Chi Kuadrat hitung (x2hitung $=3,376)$ kemudian nilai tersebut dibandingkan dengan Chi Kuadrat tabel $(x 2 t a b e l=11,070)$. Hal ini menunjukkan bahwa x2hitung < x2tabel berarti data hasil kompetensi pengetahuan matematika kelompok kontrol berdistribusi normal. 
Pengujian homogenitas varians antar kelompok dimaksudkan untuk meyakinkan bahwa perbedaan yang diperoleh uji-t benar-benar berasal dari perbedaan antar kelompok bukan disebabkan oleh perbedaan di dalam kelompok. Uji homogenitas varians yang dilakukan dalam pene-litian ini menggunakan uji $\mathrm{F}$. Dari hasil analisis, diperoleh Fhitung= 1,36 dan Ftabel $=1,82$. Hal ini berarti Fhitung $<$ Ftabel , sehingga data kedua kelompok memiliki varians yang homogen. Berdasarkan hasil uji prasyarat yang terdiri dari uji normalitas dan uji homogenitas varians, disimpulkan bahwa data kedua kelompok sampel ialah berdistribusi normal dan memiliki varians yang homogen. Dengan demikian, uji hipotesis menggunakan uji-t dapat dilakukan.

Hipotesis yang diuji dalam pe-nelitian ini adalah tidak terdapat perbedaan yang signifikan kompe-tensi pengetahuan matematika antara siswa kelas V SD Gugus II Kuta Utara tahun pelajaran 2017/2018 yang dibelajarkan menggunakan model pembelajaran team assisted individualization berbasis penilaian kinerja dan yang dibelajarkan menggunakan pembelajaran konvensional.

Hasil uji prasyarat yang meliputi uji normalitas dan homogenitas varians yang dilakukan dalam penelitian ini diperoleh kedua kelompok sampel berdistribusi normal dan memiliki varians yang homogen. Analisis statistik yang digunakan un-tuk menguji hipotesis penelitian ini adalah uji-t dengan separated varians. Berdasarkan hasil perhi-tungan uji-t, diperoleh thitung $=4,072$ dan untuk taraf signifikansi $5 \%$ dengan $\mathrm{dk}=(33+33-2)=64$ diperoleh ttabel $=2,000$. Dengan demikian, nilai thitung $>$ ttabel yakni $4,072>2,000$ sehingga $\mathrm{H} 0$ ditolak.

Perhitungan.rekapitulasi hasil analisis uji-t kelompok sampel penelitian ini disajikan dalam tabel berikut.

Tabel 1. Rekapitulasi Hasil Aanalisis Data Kompetensi Pengetahuan matematika Menggunakan Uji-t

\begin{tabular}{rrrrrrrrr}
\hline No & Sampel & $\mathrm{N}$ & $\mathrm{Dk}$ & $\bar{X}$ & $\mathrm{~S}^{2}$ & $\mathrm{t}_{\text {hitung }}$ & $\mathrm{t}_{\text {tabel }}$ & Status \\
\hline 1 & $\begin{array}{l}\text { Kelompok } \\
\text { eksperimen }\end{array}$ & 33 & & 75,71 & 182,42 & & & \\
$\begin{array}{l}\text { Kelompok } \\
\text { kontrol }\end{array}$ & 33 & 64 & 61,00 & 248,19 & & 4,072 & 2,000 & $\begin{array}{l}\mathrm{H}_{0} \\
\text { ditolak }\end{array}$ \\
\hline
\end{tabular}

Berdasarkan uji hipotesis diperoleh thitnung $=4,072$ sedangkan pada taraf signifikansi $5 \%$ dan $\mathrm{dk}=64$ diperoleh nilai $\mathrm{t}_{\text {tabel }}=2,000$ sehingga thitnung $=4,072>\mathrm{ttabel}=2,000$. Dengan demikian, hipotesis nol $\mathrm{HO}$ di tolak yang menyatakan bahwa tidak terdapat perbedaan yang signifikan kompetensi pengetahuan matematika kelompok siswa yang dibelajarkan melalui model pembelajaran team assisted individualization berbasis penilaian kinerja dengan kelompok siswa yang dibelajarkan melalui pembelajaran konvensional pada kelas $\mathrm{V}$ sekolah dasar Gugus II Kuta Utara tahun pelajaran 2017/2018 dan Ha diterima yang menyatakan bahwa terdapat perbedaan yang signifikan kompetensi pengetahuan matematika kelompok siswa yang dibelajarkan melalui model pembelajaran team assisted individualization berbasis penilaian kinerja dengan kelompok siswa yang dibelajarkan melalui pembelajaran konvensional pada kelas V sekolah dasar Gugus II Kuta Utara tahun pelajaran 2017/2018. Hal ini berarti terdapat pengaruh model pembelajaran team assisted individualization berbasis penilaian kinerja terhadap kompetensi pengetahuan matematika siswa kelas V SD Gugus II Kuta Utara tahun pelajaran 2017/2018.

Perolehan hasil perhitungan analisis data yang dilakukan menunjukkan bahwa nilai rerata siswa yang dibelajarkan team assisted individualization berbasis penilaian kinerja ( $=75,71$ ) dengan perolehan nilai terendah 48 dan nilai tertinggi 92, sesuai dengan analisis nilai kompetensi pengetahuan matematika siswa pada kelompok eksperimen. Hasil rata-rata siswa yang dibelajarkan menggunakan pembelajaran konvensional $(=61,00)$ dengan perolehan nilai terendah 32 dan nilai tertinggi 92, sesuai dengan analisis nilai kompetensi pengetahuan matematika siswa pada kelompok kontrol. 
Hasil perolehan rata-rata kelompok eksperimen dan kelompok kontrol memiliki perbedaan sebesar 14,71. Dengan demikian, terdapat pengaruh kompetensi pengetahuan matematika antara siswa kelas V di SD Gugus II Kuta Utara tahun pelajaran 2017/2018 yang dibelajarkan menggunakan model pembelajaran team assisted individualization berbasis penilaian kinerja dan siswa yang dibelajarkan menggunakan pembelajaran konvensional.

Berdasarkan hasil analisis data, dapat dinyatakan kedua kelompok sampel penelitian yang memiliki kemampuan setara, setelah diberikan perlakuan berupa team assisted individualization berbasis penilaian kinerja yang menggunakan pembelajaran konvensional diperoleh hasil kompetensi pengetahuan matematika yang berbeda. Hal ini dapat dilihat juga dari $\bar{X}$ siswa yang mengikuti pembelajaran menggunakan model pembelajaran team assisted individualization berbasis penilaian kinerja lebih tinggi dibandingkan dengan $\bar{X}$ siswa yang mengikuti pembelajaran konvensional. Perbedaan hasil kompetensi pengetahuan dengan perolehan nilai rerata yang lebih tinggi pada kelompok eksperimen dibandingkan kelompok kontrol disebabkan oleh perlakuan berupa model pembelajaran team assisted individualization berbasis penilaian kinerja dalam kompetensi pengetahuan matematika diberikan pada kelompok eksperimen.

Pada kelompok eksperimen, kegiatan pembelajaran dalam kompetensi pengetahuan matematika team assisted individualization berbasis penilaian kinerja berjalan dengan optimal dan kondusif. Hal ini disebabkan oleh pembelajaran dengan model team assisted individualization berbasis penilaian kinerja akan membuat siswa lebih aktif dalam pembelajaran serta lebih percaya diri dan meningkatkan kinerjanya dalam pembelajaran.

Shoimin (2014) menyatakan bahwa kelebihan dari model pembelajaran team assisted individualization sebagai berikut : "model pembelajaran team assisted individualization dapat membantu siswa yang lemah dapat dalam menyelesaikan masalahnya, dapat membantu siswa yang pandai untuk mengembangkan kemampuan dan keterampilannya". Berbeda pada kelompok kontrol, kegiatan pembelajaran dengan pembelajaran konvensional berjalan kurang optimal. Hal ini disebabkan pembelajaran konvensional masih sangat pasif dan monoton. Pembelajaran menggunakan model pembelajaran team assisted individualization berbasis penilaian kinerja pada muatan materi matematika memberikan kesempatan yang lebih luas kepada siswa untuk mengonstruksikan pengetahuannya bersama anggota kelompoknya. Dengan demikian, perbedaan hasil kompetensi pengetahuan matematika dapat terlihat dari langkah pembelajaran yang dilakukan pada kedua kelompok tersebut, hasil analisis uji hipotesis, dan nilai rerata kelompok siswa yang mengikuti pembelajaran menggunakan model pembelajaran team assisted individualization dengan siswa yang mengikuti pembelajaran konvensional. Dengan demikian, perbedaan hasil kompetensi pengetahuan matematika dapat terlihat dari langkah pembelajaran yang dilakukan pada kedua kelompok tersebut, hasil analisis uji hipotesis, dan nilai rerata kelompok siswa yang mengikuti pembelajaran menggunakan model pembelajaran team assisted individualization berbasis penilaian kinerja dengan siswa yang mengikuti pembelajaran konvensional.

Hasil temuan pada penelitian ini memiliki persamaan dengan penelitian sebelumnya yang relevan dan memperkuat hasil penelitian yang diperoleh, Hal tersebut didukung hasil penelitian yang diajukan oleh Nurissa (2016) yang menyatakan terdapat perbedaan yang signifikan kompentensi belajar matematika antara kelompok siswa yang dibelajarkan dengan model pembelajaran team assisted individualization dan kelompok siswa yang dibelajarkan dengan pembelajaran konvensional, Penelitian yang dilakaukan oleh Marudewi (2014) yang menyatakan terdapat perbedaan yang signifikan hasil belajar matematika antara kelompok siswa yang dibelajarkan dengan model pembelajaran kooperatif tipe team assisted individualization berbasis peta konsep dan kelompok siswa yang dibelajarkan dengan pembelajaran konvensional dan penelitian yang dilakukan oleh Pramana (2014) yang menyatakan terdapat perbedaan yang signifikan hasil belajar matematika antara kelompok siswa yang dibelajarkan dengan model pembelajaran kooperatif tipe team assisted individualization berbasis niali karakter dan kelompok siswa yang dibelajarkan dengan pembelajaran konvensional. 
Dengan demikian, pembelajaran menggunakan model pembelajaran team assisted individualization berbasis penilaian kinerja pada penelitian ini memiliki keunggulan yakni dapat meningkatkan prestasi belajar siswa, mampu memperdalam pamahaman siswa, melatih tanggung jawab siswa, menyenangkan siswa dalam belajar, mengembangkan rasa ingin tahu siswa, meningkatkan rasa percaya diri siswa, mengembangkan rasa saling memiliki dan kerjasama, setiap siswa termotivasi untuk menguasai materi, menghilangkan kesenjangan antara yang pintar dengan tidak pintar, tercipta suasana gembira dalam belajar, dan dapat meningkatkan kinerja siswa dalam pembelajaran.

\section{Simpulan dan Saran}

Berdasarkan hasil analisis data kompetensi pengetahuan matematika pada kelompok eksperimen terdapat 33 siswa dengan nilai tertinggi yang diperoleh 92 dan nilai terendah adalah 48. Dari sebaran data tersebut diperoleh data rata-rata (mean) adalah 75,71 yang berdasarkan PAP skala 5 termasuk kriteria cukup. Berdasarkan hasil analisis data kompetensi pengetahuan matematika pada kelompok kontrol terdapat 33 siswa dengan nilai tertinggi yang diperoleh 92 dan nilai terendah adalah 32. Dari sebaran data tersebut diperoleh data rata-rata (mean) adalah 61,00 yang berdasarkan PAP skala 5 termasuk kriteria kurang. Dari hasil analisis diketahui bahwa sebaran data kompetensi pengetahuan matematika siswa berdistribusi normal dan memiliki varians yang homogen. Dari hasil analisis diperoleh thitung $=4,072$ dan ttabel $=2,000$ pada taraf signifikansi $5 \%$ dengan $\mathrm{dk}=$ 64. Oleh karena thitung 4,072 > ttabel 2,000 maka $\mathrm{HO}$ di tolak yang menyatakan bahwa tidak terdapat perbedaan yang signifikan kompetensi. pengetahuan matematika kelompok siswa yang dibelajarkan melalui model pembelajaran team assisted individualization berbasis penilaian kinerja dengan kelompok siswa yang dibelajarkan melalui pembelajaran konvensional pada kelas V sekolah dasar Gugus II Kuta Utara tahun pelajaran 2017/2018 dan $\mathrm{Ha}$ diterima yang menyatakan bahwa terdapat perbedaan yang signifikan kompetensi pengetahuan matematika kelompok siswa yang dibelajarkan melalui model pembelajaran team assisted individualization berbasis penilaian kinerja dengan kelompok siswa yang dibelajarkan melalui pembelajaran konvensional pada kelas V sekolah dasar Gugus II Kuta Utara tahun pelajaran 2017/2018.

Ada bebrapa saran yang dapat diajukan berdasarkan temuan dan kajian penelitian ini adalah sebagai berikut:

1) Kepada Guru

Berdasarkan simpulan penelitian yang diperoleh, disarankan kepada guru agar lebih kreatif untuk memberikan fasilitas berupa sumber belajar dan kesempatan yang lebih besar bagi siswa pada pembelajaran yang menggunakan model pembelajaran team assisted individualization berbasis penilaian kinerja dan dapat dijadikan alternatif dalam proses pembelajaran untuk membantu peserta didik meningkatkan kompetensi pengetahuan matematika dengan maksimal.

2) Kepada Sekolah

Berdasarkan simpulan penelitian, disarankan kepada sekolah agar dapat menggunakan hasil penelitian ini sebagai sebagai alternatif dalam mengelola pembelajaran agar sesuai dengan karakteristik pembelajaran matematika, sehingga mampu meningkatkan pengetahuan dan pemahaman peserta didik tentang matematika.

3) Kepada Peneliti lain

Berdasarkan simpulan penelitian, disarankan kepada peneliti lain agar hasil penelitian ini digunakan sebagai suatu acuan bagi peneliti lain untuk mengembangkan kemampuan diri dalam mempersiapkan diri sebagai calon pendidik dan meningkatkan pemahaman mengenai kurikulum 2013 dengan penerapan model pembelajaran team assisted individualization berbasis penilaian kinerja. 


\section{Daftar Pustaka}

Darmadi, Hamid. 2011. Metode Penelitian Pendidikan. Bandung: Alfabeta.

Depdiknas. 2003. Kurikulum 2004 Standar Kompetensi untuk Kelas V Sekolah Dasar. Jakarta: Depdiknas.

Fahturrohman, Muhammad. 2015. Model-Model Pembelajaran Inovatif. Yogyakarta: ArRuzz Media.

Kosasih. 2014. Strategi Belajar Dan Pembelajaran. Bandung : Yrama Widya

Merudewi, I.G. A. Kencana. 2014. Pengaruh Model Pembelajaran Kooperatif Tipe TAI (Team Assisted Individualization) Berbasis Peta Konsep Terhadap Hasil Belajar IPS Siswa Kelas V SD Gugus VIII Sukawati. Jurnal: Undiksha.

(Diakses dari https://ejournal.undiksha.ac.id/index.php/JJPGSD/article/view/1917 Pada tanggal 27 Februari 2018 jam 15.20)

Nurissa, Dwi Setia. 2016. Pengaruh Model Pembelajaran Kooperatif Tipe Team Assisted Individualizaion (TAI) Terhadap Hasil Belajar Mata Pelajaran Matematika Kelas IV Siswa Kelas IV SD Muhammadiyah Karangharjo Berbah Sleman. Skripsi: Universitas Negeri Yogyakarta. pdf.(Diakses dari https://skripsi.Yogya.ac.id/index.php/JJPGSD/article/ Pada tanggal 12 Februari 2018. Jam 15.16)

Pramana, I Nyoman Arya. Pengaruh Model Pembelajaran Team Assisted Individualzation Berbasis Nilai-Nilai Karakter Terhadap Hasil Belajar IPS Kelas IV. Jurnal: Undiksha. pdf.(Diakses dari https://ejournal.undiksha.ac.id/index.php/JJPGSD/article/view/1917 Pada tanggal 27 Februari 2018 jam 16.10)

Sugiyono. 2013. Metode Penelitian Pendidikan Pendekatan Kuantitatif dan Kualitatif, dan $R \& B$. Bandung: Alfabeta.

Sugiyono. 2014. Metode Penelitian Pendidikan Pendekatan Kuantitatif dan Kualitatif, dan $R \& B$. Bandung: Alfabeta.

Supardi. 2015. Penilaian Autentik. Jakarta: Rajawali.

Sohimin, Aris. 2014. 68 Model Pembelajaran Inovatif dalam Kurikulum 2013. Yogyakarta: Ar-Razz Media. 